\title{
Introduction to Engineering Course - High School Partnership
}

\author{
Taryn Melkus Bayles \\ Department of Chemical and Biochemical Engineering \\ University of Maryland Baltimore County
}

\section{Introduction}

UMBC has undertaken three major initiatives to improve engineering education and awareness. The first initiative was to develop and present a three-day summer workshop to introduce high school teachers and counselors to the field of engineering. The second initiative was to revamp the Introduction to Engineering Course (ENES 101) to include hands-on project based inquiry experience, in which the students are required to research, design, construct, test, model, evaluate, and report on a specified product. The revised ENES 101 course was presented and discussed during a summer workshop, which lead to the faculty at Eastern Technical High School's request for the development of a formal partnership (the third initiative) with UMBC to teach the equivalent of the ENES 101 course in the high school environment. It is not the intent of the partnership to be a recruiting tool for $\mathrm{UMBC}$, but rather to expose high school students to a college level introductory engineering course.

\section{Background}

The high school level Introduction to Engineering course was developed based on the interest and ideas that emerged from a workshop conducted at UMBC in July 2001. The objective of the workshop was to better equip high school teachers and counselors to identify, guide, and prepare prospective students at each of their schools for a career in engineering. The three-day workshop was developed and presented by UMBC faculty from the College of Engineering and was modeled after work done by Raymond Landis ${ }^{1}$, former Dean of Engineering and Technology at California State University, Los Angeles. Invitations to the workshop with a brochure and application form were sent to area high schools in Maryland. Each participant received a $\$ 150$ stipend, meals, and Maryland State Department of Education (MSDE) continuing education credits. The workshop was sponsored by a grant from the University System of Maryland through their K-16 Disciplinary Alliance and matching funds from UMBC's College of Engineering (COE).

Twenty-eight mathematics, technology, and science high school teachers and counselors attended and explored the spectrum and reach of engineering in society. The following topics were covered during the workshop:

- An introduction to the broad field of engineering

"Proceedings of the 2003 American Society for Engineering Education Annual Conference \& Exposition Copyright $@ 2003$, American Society for Engineering Education" 
- Student panel discussion on what it takes to be an engineering student

- Overview of the freshman Introduction to Engineering course at UMBC

- High school preparation for an engineering career, including math and science

- Future Scientists and Engineers of America (FSEA) program overview and competition

- Tour of local engineering facilities at Northrop Grumman

- Engineering faculty panel discussion on various engineering disciplines

- Opportunities and rewards of an engineering career

- Use of the Internet to learn about engineering

- 'Hands-on' projects to help introduce high school students to engineering

- Engineering alumni panel discussion on the future needs of industry

- Engineering research projects

○

- Success strategies students might use in pursuit of an engineering career

- Overview of engineering education, including curriculum, facilities, resources and opportunities for students

The approach taken in presenting many of the topics was to provide fun 'hands on' activities, during which the participants competed for a variety of 'prizes,' including UMBC t-shirts, key chains, and gift certificates. Pre and post-surveys were conducted to assess the knowledge, abilities, and understanding of the participants in the following categories:

1. Knowledge of the various engineering disciplines.

2. Understanding of the opportunities and rewards of an engineering career.

3. Understanding of what high school preparation is needed to pursue an engineering degree.

4. Knowledge of programs available to introduce students to engineering.

5. Knowledge of strategies to help prepare students to be successful in high school and college.

6. Ability to incorporate projects into the classroom to help introduce high school students to engineering.

7. Comfort level in advising students for an engineering career.

Figures 1 and 2 below highlight the results of the surveys. Each category showed significant improvement, with the largest improvement in the participant's ability to incorporate introductory engineering projects into the classroom and their comfort level in advising students for an engineering career. 


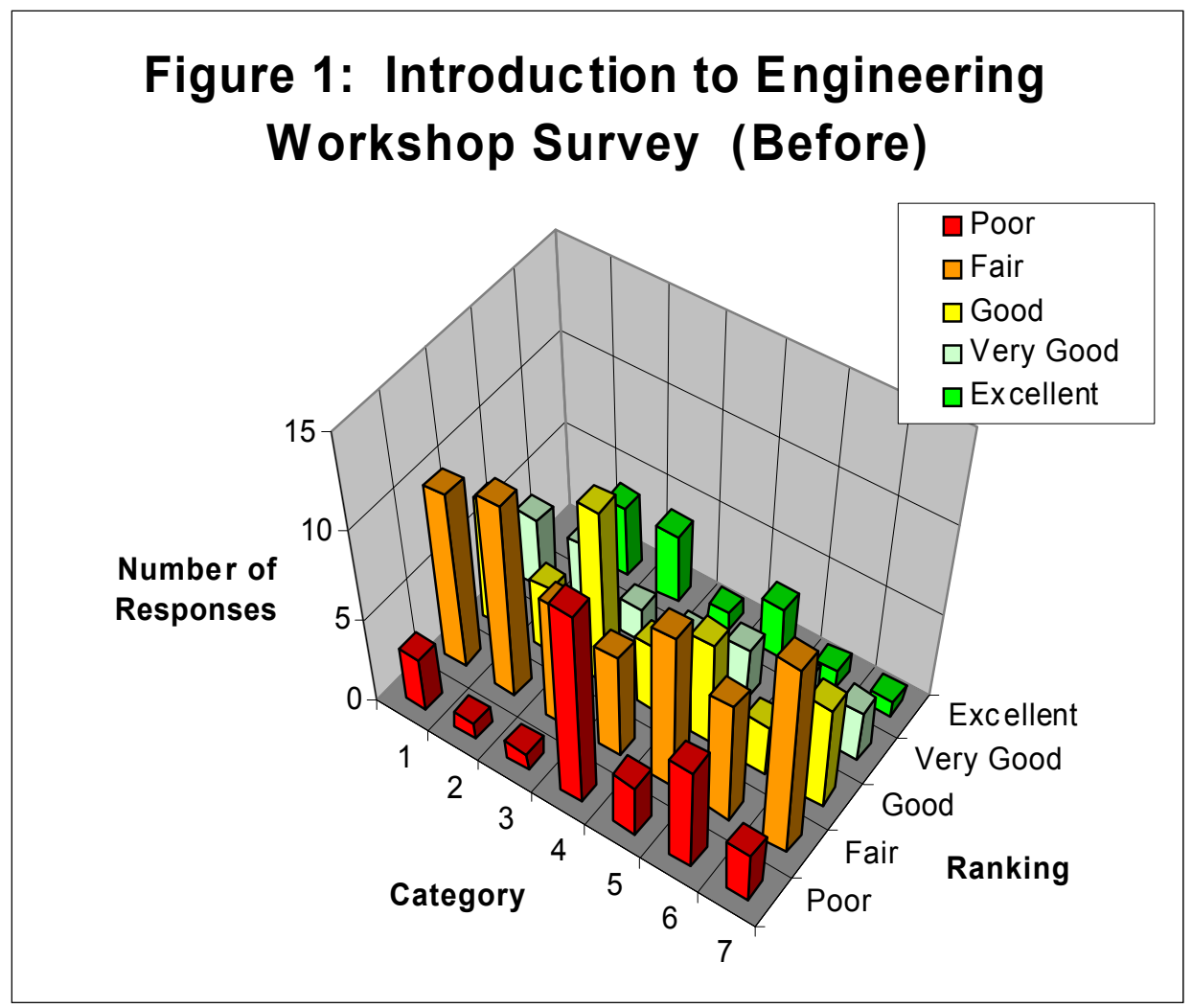

"Proceedings of the 2003 American Society for Engineering Education Annual Conference \& Exposition Copyright (C2003, American Society for Engineering Education”" 


\section{Figure 2: Introduction to Engineering Workshop Survey (After)}

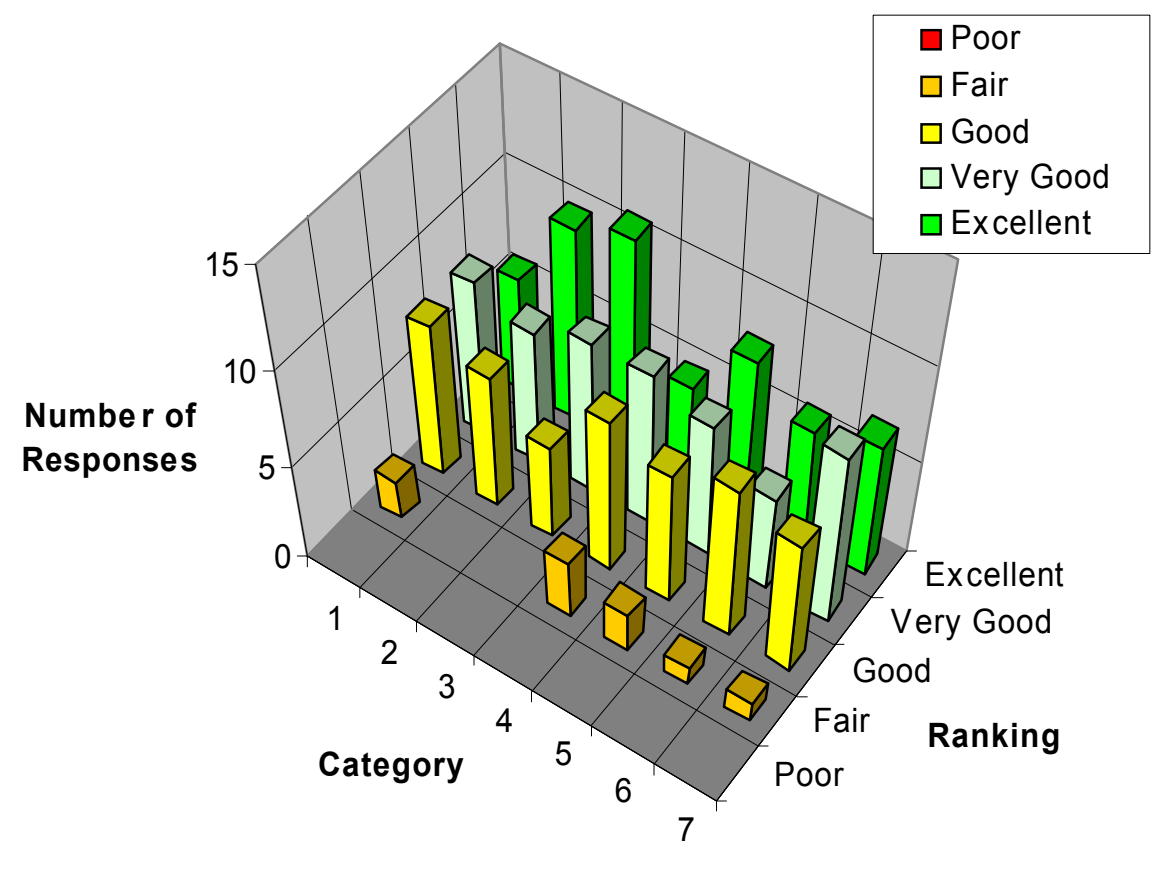

Another, possibly more revealing, measure of the success of this workshop was the interest it generated in follow-up collaborations between UMBC and local high schools. A few examples include:

- Invitations for UMBC to make several high school career day presentations.

- Numerous high school class visits and tours of UMBC's College of Engineering.

- UMBC's participation in the establishment of a High School Engineering Academy.

- New partnerships forming the basis of grant proposals to NSF in Engineering Education Program and the Maryland High Education Commission (MHEC).

- The formation of a high school level Introduction to Engineering course and the subsequent pilot field introduction of this course in a partnership between UMBC and Eastern Technical High School.

It is the last of these activities, the high school level Introduction to Engineering course, that is the subject of the present paper.

\section{Objectives of the Introduction to Engin eering Course - High School Partnership}

The objective of the UMBC - high school partnership is to expose high school students to a

"Proceedings of the 2003 American Society for Engineering Education Annual Conference \& Exposition Copyright (C2003, American Society for Engineering Education”" 
college level Introduction to Engineering course. Instruction is achieved using a teamwork approach. The course introduces students to the following elements:

- The product development process, including product research, design, analysis and evaluation, and presentation.

- Basic engineering and scientific principles needed to develop a specific design.

- Computer skills, including applications software, computer aided design, and programming.

- Engineering fundamentals such as data analysis, strength of materials, statics, fluid mechanics, heat transfer, and computer programming are also studied.

By the end of the course, each student has had opportunities to further his/her professional development through teamwork; practicing written, oral, and graphical communication skills; using modern computer tools; and acquiring an appreciation for life-long learning.

\section{The Model - Introduction to Engineering Course at UMBC}

The Introduction to Engineering course (ENES 101) at UMBC was revamped in 2001 and has its origins in work done by Dally and Zhang ${ }^{2}$, and in work the author did while teaching in the Freshman Engineering ECSEL ${ }^{3}$ program at the University of Maryland, College Park. ENES 101 includes an overview of engineering and an introduction to various topics within engineering. The emphasis of the revision of the course was to make it a project based inquiry experience. The students must work in interdisciplinary teams to design, build, evaluate, test, and report (both a formal written report and oral presentation) on a specified product. ENES 101 is a three-credit freshman engineering course which consists of two fifty-minute class sessions and a two-hour discussion session each week over a 16 week semester. The enrollment in this course is approximately 120 students in the fall semester and 60 students in the spring semester. The discussion sessions are limited to 30 students. The course has three primary components: engineering topics, design tools, and the design project.

Since the majority of the students in the course are incoming freshman, the first few classes are devoted to educating students on how they can be successfull ${ }^{4-6}$ in studying engineering, discussing the engineering profession, providing academic strategies for success, and showing students how they can broaden their education. Also as part of the course each student is required to participate in at least one function sponsored by a student professional engineering society (AIChE, ASME, IEEE, SAE, etc.). This is a chance for the students to make connections with upperclassmen in their major and become acquainted with the various opportunities available. A variety of engineering topics are covered during class including unit conversion and dimensional consistency, data analysis and representation, strength of materials, introduction to statics, introduction to fluid mechanics, introduction to heat transfer, and computer programming. Depending on the design project topic, some of the topics are studied in more depth. A workbook, written by the present author, is given to each student and covers the course topics

"Proceedings of the 2003 American Society for Engineering Education Annual Conference \& Exposition Copyright $\mathbb{0} 2003$, American Society for Engineering Education” 
complete with example problems. These example problems supplement problems covered during class.

The students are instructed in the use of various design tools during the weekly two-hour discussion sessions. Most of the sessions are held in the dedicated COE freshman computer lab. Undergraduate Teaching Fellows ${ }^{7}$, who are senior-level engineering students lead the discussion sessions. The Fellows are recruited by the instructor and have demonstrated their ability to work well with students due to their previous experience in taking ENES 101 at UMBC and demonstrating both collaboration and leadership in the classroom. The design tools include Microsoft Word, Microsoft Excel, computer aided design (CAD), computer programming, and Microsoft PowerPoint. The Engineer's Toolkit: A First Course in Engineering (An AddisonWesley Select Edition published by The Benjamin/Cummings Publishing Company, Inc.) series of workbooks is used for the discussion session exercises and homework assignments. The Teaching Fellows are responsible for grading the weekly homework assignments (prepared by the instructor), which includes material covering both the design tools and class topics. Student teams meet during discussion sessions as well as outside of class to work on their design projects.

Each year a different design project is selected and the students must research, design, construct, and develop an analytical model and then test, evaluate, and report on the product. The goal is to select a product that is fun ${ }^{8}$, inexpensive to construct, simple, and yet requires fundamental engineering principles. Safety is the primary concern, and the design specifications are structured to include safety precautions. The projects are also structured to have "bragging rights" associated with the product performance. This has resulted in friendly competition among the teams. Successful projects have included: human powered pumps for pumping water up a vertical height of 10 feet, catapults or trebuchets used to launch water balloons for distance and accuracy at a target (which included the faculty member), and hot air balloons ${ }^{9}$ that were required to carry a minimum payload and stay aloft a minimum time period. The projects are introduced during class by having the students take apart simple soap dispensers or toy catapults to see how they work ${ }^{10}$. The homework assignments have problems that lead the students in the right direction for the modeling and product performance calculations that are required. It has been rewarding to see the creative designs ${ }^{11}$, as well as the interest the teams have taken in the projects. Many teams have created videos they made during the construction and testing of their projects. UMBC's Office of Information Technology has also filmed the design process over the course of the semester and has produced a video ("Video Tech Watch: Innovations in Engineering Education" produced by Bob Kuhlmann and Damion Wilson of UMBC's New Media Studio www.umbc.edu/oit/newmedia/real/tarynbayles.ram). Local interest in the design projects has also occurred with local television coverage and articles in local newspapers ('In experiment, it's ready, aim, inspire' by Alec Mac Gillis in The Baltimore Sun, May 8, 2002). This publicity has resulted in numerous contacts from area high schools that are interested in partnering with $\mathrm{UMBC}$, as well as calls from prospective students and parents.

The first homework assignment consists of a team application form for each student to complete. Information regarding the students' major, high school attended, GPA, SAT scores, and access to 
a car are requested. The students are also required to identify their skills in writing, graphics, leadership, teamwork, analysis, drafting, planning and research/library, as well as their strengths and weaknesses. This information is then used to assign the teams ${ }^{12}$, which consist of 4-6 team members. Teams are balanced using the following criteria: major ${ }^{13}$, background, academic performance, gender and ethnicity ${ }^{14}$, and access to transportation off campus to purchase materials for the construction of the project. The team application also requires the students to write about themselves: how they became interested in their major, what their long-term career goals are, and what they did over the last summer or winter break. This information is used solely by the instructor to get to know the students on a more personal level since the class sizes are large. After the team assignments are made, (by the end of the second week of the semester), class time is then spent learning to effectively build and work in a team ${ }^{15,16}$.

Communication skills are stressed as part of the design project experience. Each team must complete a logbook ${ }^{17}$ over the course of the semester; the first team assignment is to interview each team member and log the interviews. The remainder of the entries serves as documentation of team meetings, evolution of design, modeling, evaluation approaches, and actual performance. Each team must also submit a final written report summarizing their efforts. Guidelines for the report, as well as a detailed grading rubric ${ }^{18}$ are handed out and discussed during class. The teams are encouraged to turn in a preliminary draft of their report for comments prior to submitting their final report. UMBC also has a Writing Center located in the Learning Resource Center on campus that provides assistance to the students in the preparation of their reports ${ }^{19}$. Each team is also required to make a formal oral presentation using PowerPoint and each team member is required to present. Specific guidelines for the presentation are discussed in class and the students are given a grading rubric for the presentation. Each team member must also complete a peer evaluation on themselves and each team member, which is part of the students' grade for the course.

\section{The Pilot High School Engineering Course}

The high school course is essentially the same as UMBC's ENES 101 course. The same workbook, Engineer's Toolkit, homework assignments, quizzes and exams are given, as well as the same design project and evaluation criteria. The differences between the two experiences are that the high school course is taught over a full school year, versus a semester; therefore, the students have more class time to work on their design projects and assignments. The high school teams usually have time to complete two different design projects (the current UMBC project and a previous project). In addition, the high school teams are composed of only two or three students since it has been the experience of the high school teachers that groups of more students are less effective.

As part of a field trip, the high school students are required to attend one of the design project testing days during the fall semester at UMBC. This gives them the opportunity to experience the climate and culture of a college campus as well as meet and talk with some of the college students

\footnotetext{
"Proceedings of the 2003 American Society for Engineering Education Annual Conference \& Exposition
} Copyright ${ }^{0} 2003$, American Society for Engineering Education” 
and learn from their designs. The high school students also attend a UMBC visit day where they attend engineering classes, a COE discipline overview, a student panel discussion, and a campus tour. Interested students also attend the COE open house during Engineers Week. Also as part of this exchange, the author travels to the high school for the design project testing and the oral presentations.

\section{The Pilot Site - Eastern Technical High School}

At the conclusion of the three day summer workshop, Eastern Technical High School requested UMBC to partner with them in the fall of 2001 to assist them in teaching their senior level engineering course, which is part of their Engineering Careers program. Eastern Tech serves students primarily from northern and eastern Baltimore County, Maryland. Eastern Tech has been named a New American High School National Showcase Site by the U.S. Department of Education and the National Association of Secondary School Principles, as well as a Maryland Blue Ribbon School of Excellence by the Maryland State Department of Education. With an enrollment of 1330, Eastern Tech offers a comprehensive academic and technical education to students who successfully complete eighth grade and fulfill its highly competitive application process. Eastern Tech is the technology magnet school for eastern Baltimore County and offers advanced placement, gifted and talented, and honors level courses in English, mathematics, science and social studies. Eastern Tech emphasizes state of the art technology and offers ten career majors including the Engineering Career major.

The Engineering Careers program is designed for highly motivated high school students who intend to enter a college engineering program. The program emphasizes the preparation of each student for the rigorous natural science, mathematics, and computer programming courses required for the mastery of an engineering curriculum. In addition, the Engineering Careers program exposes students to the different disciplines of the profession. The program culminates in the senior level engineering course, which is the equivalent of UMBC's ENES 101 course. The students that complete this high school course (in addition to the required computer aided drafting and design and computer programming courses) are eligible to receive credit for ENES 101 if they elect to attend UMBC.

The senior level high school engineering course (enrollment is 25-30 students) is taught by Mr. James Matalavage, who worked as an engineer for seven years prior to becoming a high school engineering teacher 11 years ago. He also serves on the Industrial Advisory Board of UMBC's COE.

\section{Results and Conclusions}

UMBC has revamped their introduction to engineering course to include a hands-on project-based inquiry experience in the design of specified product. The University also developed and taught a three day summer workshop to introduce the field of engineering to high school teachers and counselors. This has resulted in numerous follow-up collaborations between UMBC and local

\footnotetext{
"Proceedings of the 2003 American Society for Engineering Education Annual Conference \& Exposition
} Copyright $\mathbb{0} 2003$, American Society for Engineering Education” 
area high schools. One such collaboration was a partnership to teach the introduction to engineering course in the high school setting.

As a metric of the effectiveness of the course, at the college and high school levels, some key criteria established by ABET for assessing engineering programs were used. In order to receive accreditation, ABET requires that engineering programs demonstrate that their graduates have:

(a) an ability to apply knowledge of mathematics, science and engineering

(b) an ability to design and conduct experiments, as well as to analyze and interpret data

(c) an ability to design a system, component, or process to meet desired needs

(d) an ability to function on multi-disciplinary teams

(e) an ability to identify, formulate and solve engineering problems

(g) an ability to communicate effectively

(i) a recognition of the need for, and an ability to engage in life-long learning

(k) an ability to use the techniques, skills, and modern engineering tools necessary for engineering practice.

Although it is unlikely that a single freshman engineering course can prepare students to satisfy the ABET criteria, it is useful to gauge student's progress in their abilities to utilize key engineering concepts and thought processes. To this end, students are asked to provide a self assessment, via a survey, of their progress in key ABET areas. Although results are not yet available for the high school pilot (to be available in June 2003), survey results from the Fall 2002 UMBC freshman course are available and presented below in Figure 3. 


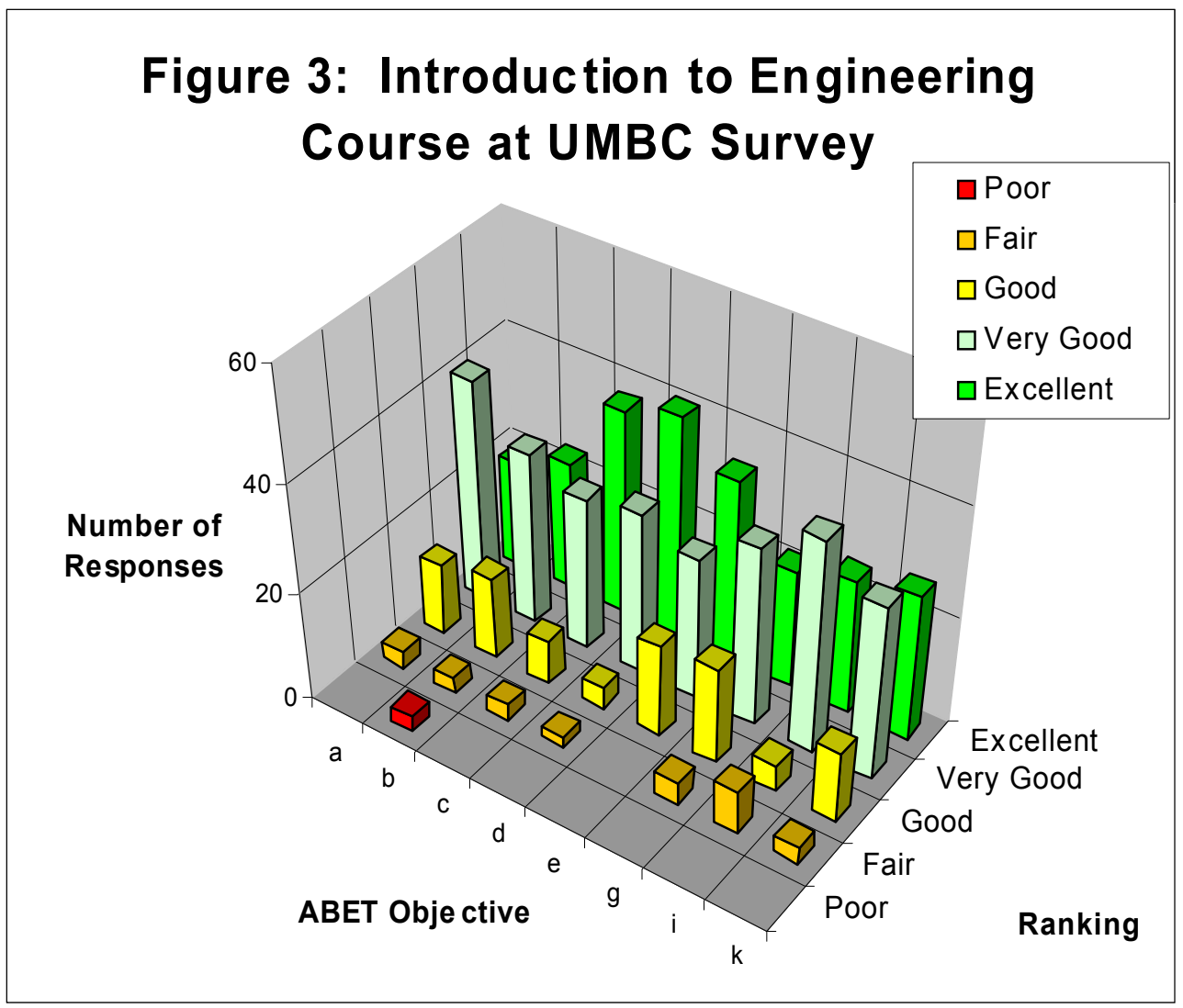

The survey measures the students' self-perceived attitudes and comfort level in key ABET areas. The proof of their progress can be readily seen in the working products they design and produce in each of the engineering challenges. Examples are given here (more can be found on the ENES 101 website: http://www.umbc.edu/engineering/101.html). In fall 2000 the teams had to design a human powered pump that had to pump water up a vertical height of 10 feet. Team HP3 is shown in Figure 4; their pumping rate was $18.75 \mathrm{gpm}$ (gallons per minute) (versus $22 \mathrm{gpm}$ predicted). Figure 5 depicts Team Stonehenge Technologies from the fall 2001 semester. Their project was to build a trebuchet to launch water balloons. Their furthest water balloon launch was 136 feet, and their target accuracy was $80 \%$. Their most accurate launch resulted in drenching the author from a distance of 125 feet. In fall 2002 the project was to design, build and model a hot air balloon. Team 4ME's and $1 \mathrm{ChE}$ is shown in Figure 6; their balloon stayed aloft for 1 minute 44 seconds, carried a 65 gram payload and had a $98 \%$ model accuracy. 


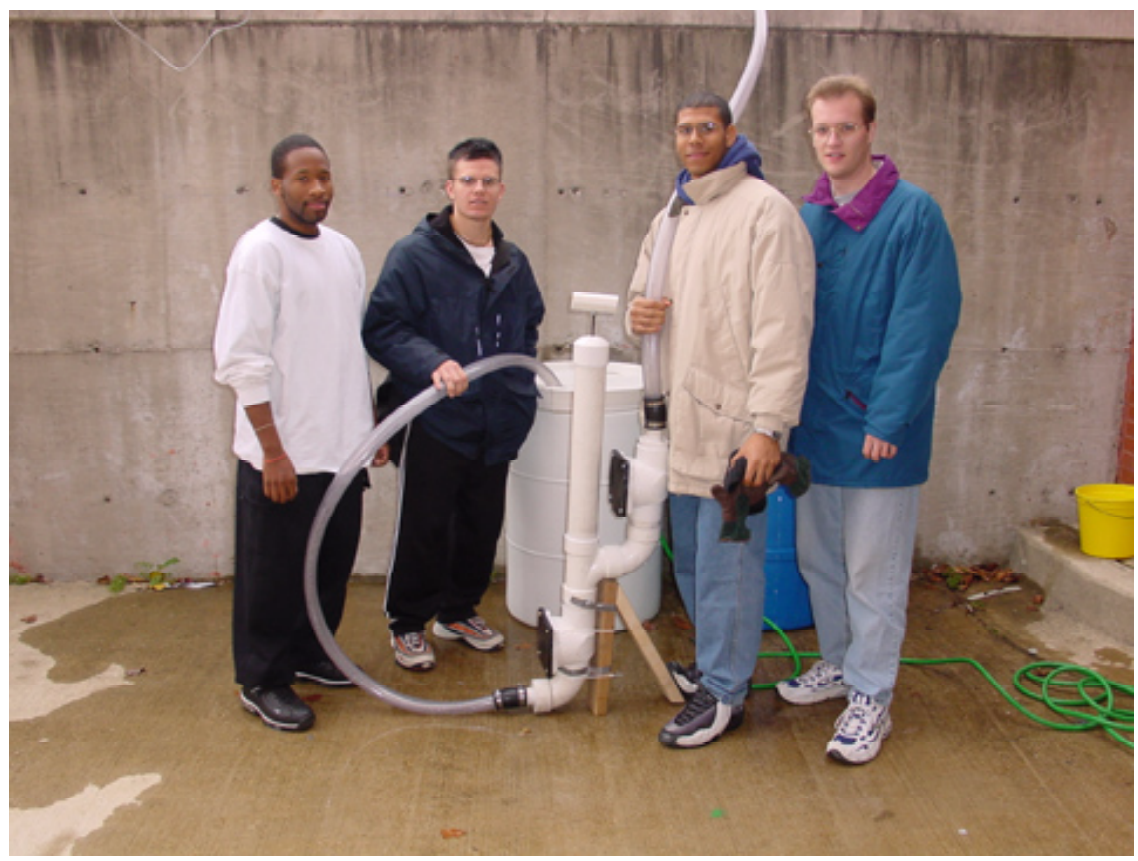

Figure 4: Team HP3; Rodney Horton, Michael Magilton, Alex Dummett and Ryan Poag.

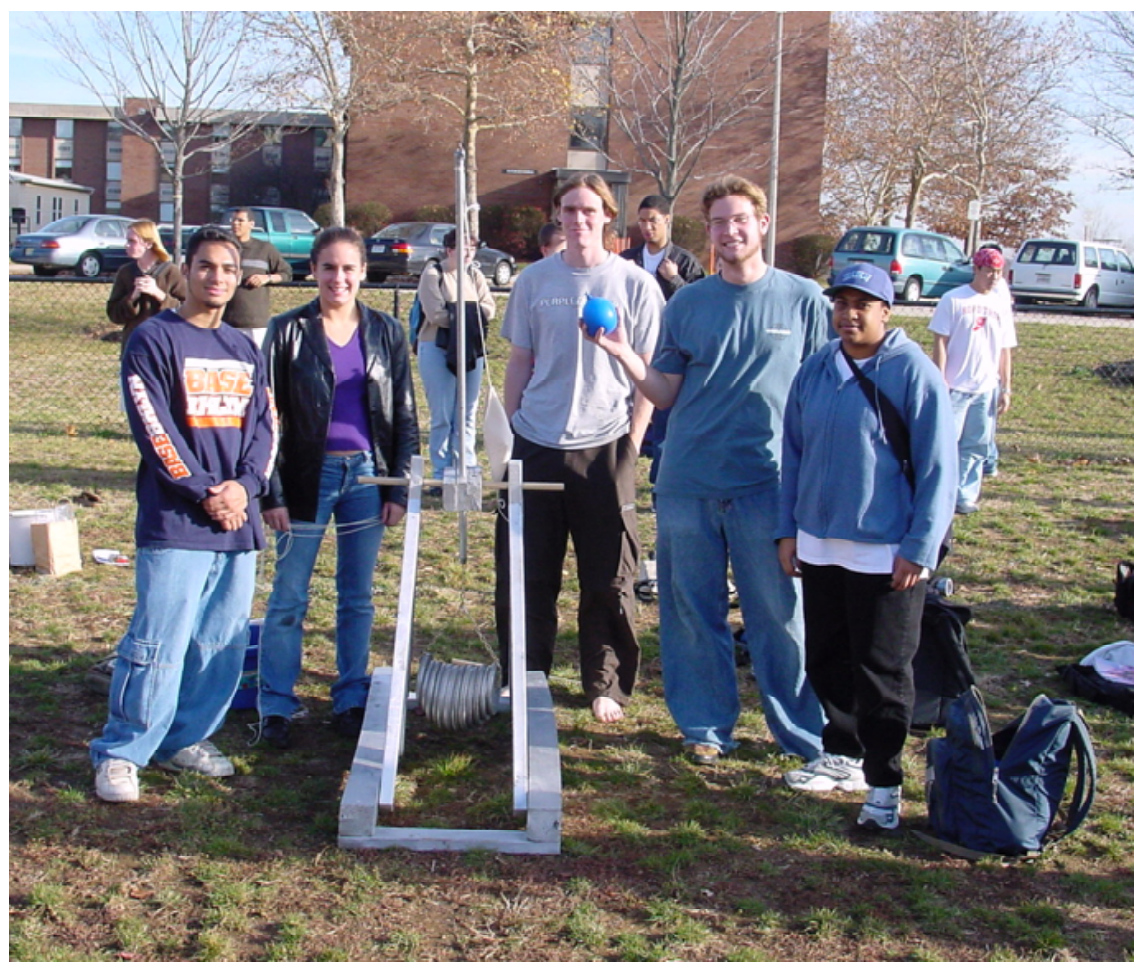

Figure 5: Stonehenge Technologies; Dennis Perez, Melissa Osborn, Whitaker Weber, Richard

"Proceedings of the 2003 American Society for Engineering Education Annual Conference \& Exposition Copyright $@ 2003$, American Society for Engineering Education " 
Boyer and Lori Hutcherson.

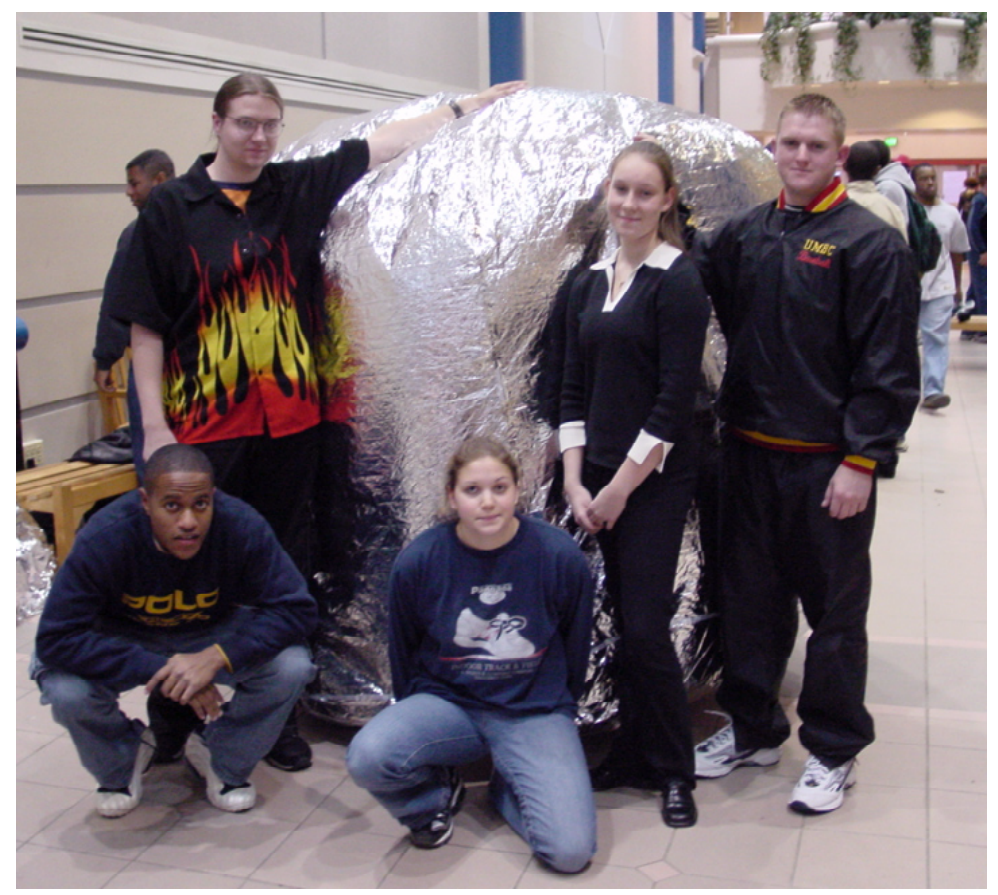

Figure 6: Team 4ME's and a CHE; Justin McGrath, Evan Griggs, April Gregory, Erika Militch and Jake Bennof.

Ninety percent of the students in the first high school class that took part in this partnership are currently majoring in engineering in college ( $24 \%$ at UMBC). The Eastern Tech high school students that enrolled at UMBC have received credit for ENES 101. It is UMBC's intent to survey the high school students once they have completed their first year of college to determine if the high school student's felt the introduction to engineering course helped prepare them for their freshman year of college. In addition, UMBC has assisted ${ }^{20}$ the high school in teaching a summer workshop for middle school girls, establishing an 'Engineering Olympics' for their feeder middle schools and starting an FSEA after school club. The high school has also partnered with us in writing grants to the NSF and MHEC. Several other area high schools have approached UMBC to establish a similar partnership. Two new high school partnerships will be initiated in the 2003-2004 academic year.

\section{Bibliographic Information}

1. Gibney, K., 1998. So What is Engineering? ASEE Prism, March: p. 14. http://www.asee.org/precollege/watis\%20-\%20article.cfm, accessed January 9, 2003.

2. $\quad$ Dally, J.W., and G.M. Zhang, “A Freshman Engineering Design Course,” Journal of

"Proceedings of the 2003 American Society for Engineering Education Annual Conference \& Exposition Copyright $\mathbb{0} 2003$, American Society for Engineering Education” 
Engineering Education, vol. 82, no. 7, 1997, pp. 41-42.

3. Al-Holou, N., N.M. Bilgutay, C. Corleto, J.T. Demel, R. Felder, K. Frair, J.E. Froyd, M. Hoit, J. Morgan, and D.L. Wells, "First Year Integrated Curricula: Design Alternatives and Examples", Journal of Engineering Education, vol. 88, no. 4, 1999, pp. 435-448.

4. Landis, R.B., Studying Engineering a Road Map to a Rewarding Career, Second Edition, Discovery Press, 2000.

5. Tietjen, J.S., K.A. Schloss, C. Carter, J. Bishop, and S.L. Kravits, Keys to Engineering Success, Prentice Hall, 2001.

6. Ainatelli, M., and M.A. Dube, “'Engineering' Student Success: How Does it Happen and Who is Responsible?," Journal of Engineering Education, vol. 88, no. 2, 1999, pp. 149-158.

7. deGrazia, J.L., J.F. Sullivan, L.E. Carlson and D.W. Carlson, "A K-12/University Partnership: Creating Tomorrow's Engineers," Journal of Engineering Education, vol. 90, no. 4, 2001, pp. 557-563.

8. Higley, K.A., and C.M. Marianno, "Making Engineering Education Fun”, Journal of Engineering Education, vol. 90, no. 4, 2001, pp. 105-107.

9. Burrows, V., personal communication August 2, 2002 and http://129.219.116.31/Featured_Lessons/con_lessons.html, accessed August 19, 2002.

10. Barr, R.E., P.S. Schmidt, T.J. Drueger, and C.Y. Twu, "An Introduction to Engineering Through an Integrated Reverse Engineering and Design Graphics Project," Journal of Engineering Education, vol. 89, no. 4, 2000, pp. 413-418.

11. Churchill, S.W., "Can We Teach Our Students to be Innovative?," Chemical Engineering Education, vol. 26, no. 2, 2002, pp. 116-121; 127.

12. Natishan, M.E., L.C. Schmidt, and P. Meade, "Student Focus Group Results on Student Team Performance Issues", Journal of Engineering Education, vol. 89, no. 3, 2000, pp. 269-272.

13. Biernacki, J.J., and C.D. Wilson, "Interdisciplinary Laboratory in Advanced Materials: a TeamOriented Inquiry-Based Approach," Journal of Engineering Education, vol. 90, no. 4, 2001, pp. 637-640.

14. Besterfield-Sacre, M., M. Moreno, L.J. Shuman, and C.J. Atman, "Gender and Ethnicity Differences in Freshmen Engineering Student Attitudes: A Cross-Institutional Study," Journal of Engineering Education, vol. 90, no. 4, 2001, pp. 477-489.

15. Seat, E., and S.M. Lord, "Enabling Effective Engineering Teams: A Program for Teaching Interaction Skills," Journal of Engineering Education, vol. 88, no. 4, 1999, pp. 385-395.

16. Adams, S.G., "The Effectiveness of the E-Team Approach to Invention and Innovation," Journal of Engineering Education, vol. 90, no. 4, 2001, pp. 597-600.

17. Brand, J.I., "The Effective Use of Logbooks in Undergraduate Classes," Chemical Engineering Education, vol. 33, no. 3, 1999, pp. 222-231.

18. Boyd, G. and M.F. Hassett, "Developing Critical Writing Skills in Engineering and Technology Students," Journal of Engineering Education, vol. 89, no. 4, 2000, pp. 409-412.

19. Walker, K., "Integrating Writing Instruction into Engineering Courses: A Writing Center Model," Journal of Engineering Education, vol. 89, no. 3, 2000, pp. 369-375.

20. Verner, I.M., and D.J. Ahlgren, "Fire-Fighting Robot Contest: Interdisciplinary Design Curricula in College and High School," Journal of Engineering Education, vol. 91, no. 3, 2002, pp. 355-359.

TARYN MELKUS BAYLES is a Visiting Lecturer and Undergraduate Program Director of the Chemical and Biochemical Engineering Department at UMBC. She has spent half of her career working in industry and the other half teaching engineering. She emphasizes practical applications from her industrial experience when teaching engineering courses. She has been recognized by her students and peers with various teaching awards.

"Proceedings of the 2003 American Society for Engineering Education Annual Conference \& Exposition Copyright $\mathbb{0} 2003$, American Society for Engineering Education” 